\title{
PENELITIAN TINDAKAN: PENINGKATAN KEMAMPUAN BERPIKIR KREATIF SISWA MELALUI MODEL ELICITING ACTIVITIES (MEA)
}

\author{
Muhammad Nurhusain ${ }^{1}$ \\ 1 Pendidikan Matematika, STKIP YPUP Makassar \\ zein.alhusain@gmail.com
}

\begin{abstract}
ABSTRAK
Kemampuan berpikir kreatif siswa yang rendah menjadi salah satu masalah dalam dunia pendidikan. Karenanya dibutuhkan model pembelajaran sebagai solusi masalah tersebut, melalui model eliciting activities. Penelitian ini bertujuan untuk meningkatkan kemampuan berpikir kreatif siswa melalui penerapan model eliciting activities. Penelitian ini merupakan penelitian tindakan kelas. Subjek penelitian adalah siswa kelas VIII SMP YP PGRI 4 Makassar tahun pelajaran 2020/2021 yang berjumlah 21 siswa. Hasil analisis deskriptif menunjukkan bahwa nilai rata-rata kemampuan berpikir kreatif siswa SMP pada Pra-PTK sebesar 50,38 dengan simpangan baku 12,897, siklus I sebesar 66,86 dengan simpangan baku 11,979, dan siklus II sebesar 81 dengan simpangan baku 10,798. Berdasarkan perolehan skor berpikir kreatif siswa, sebanyak 14,29\% (3 siswa) memiliki kemampuan berpikir kreatif tinggi sebelum PTK, dan 42,86\% (9 siswa) pada pembelajaran siklus I, naik menjadi 90,48\% (19 siswa) pada siklus II. sehingga kemampuan berpikir kreatif siswa pada siklus II terpenuhi secara klasikal. Kesimpulan yang dapat diambil adalah penerapan model eliciting activities dapat meningkatkan kemampuan berpikir kreatif siswa kelas VIII SMP YP PGRI 4 Makassar.
\end{abstract}

Kata Kunci: model eliciting activities, kemampuan berpikir kreatif.

\begin{abstract}
Students' low creative thinking ability is one of the problems in the world of education. Therefore, a learning model is needed as a solution to these problems, through a model eliciting activities. This study aims to improve students' creative thinking ability through the application of the eliciting activities model. This study is a classroom action research (CAR). The subjects were class VIII students of SMP YP PGRI 4 Makassar registered in the academic year of 2020/2021, totaling 21 students. The results of the descriptive analysis show that the average value the students' creative thinking ability in Pre-CAR at 50,38 with a standard deviation of 12,897, cycle I at 66,86 with standard deviation of 11,979, and cycle II at 81 with standard deviation of 10,798. Based on the students' creative thinking scores, as many as $14,29 \%$ (3 students) had high creative thinking ability in pre-CAR, and 42,86\% (9 students) in cycle I, rose to 90,48\% (19 students) in cycle II. So, the students' creative thinking ability after cycle II are fulfilled in classical. The conclusion that can be explain is that the application of the eliciting activities model can improve the creative thinking ability of grade VIII students of SMP YP PGRI 4 Makassar.
\end{abstract}

Keywords: eliciting activities model, creative thinking ability. 


\section{A. PENDAHULUAN}

Pendidikan merupakan kebutuhan masyarakat secara keseluruhan, namun dalam pelaksanaannya seringkali menghadapi berbagai permasalahan. Salah satu masalah yang sering muncul dalam dunia pendidikan Indonesia adalah masalah pembelajaran. Menurut Fardah (2012), "masih banyak guru SD dan SMP yang masih kurang memperhatikan kemampuan kreatif siswanya" Apalagi menurut (Abdurrozak et al., 2016), "Kemampuan kreatif siswa di Indonesia masih kurang". Selain itu, kesulitan pembelajaran matematika tidak hanya disebabkan oleh materi pelajaran matematika itu sendiri, tetapi juga karena kemampuan guru dalam mengelola pembelajaran matematika kurang efektif bila proses pembelajaran tidak melibatkan siswa dalam proses pembelajaran (Hanifah, 2015).

Berdasarkan observasi dengan guru matematika di SMP YP PGRI 4 Makassar pada tanggal 10 Februari 2020, penulis menemukan beberapa masalah atau kendala yaitu: (1) Masih banyaknya siswa yang belum mampu menyelesaikan soal matematika (2) Minimnya aktivitas siswa karena proses pembelajaran yang berpusat pada guru. Beberapa permasalahan tersebut mengakibatkan pembelajaran matematika tidak memenuhi standar ketuntasan minimal (KKM) yaitu 70. Data yang diperoleh dari observasi bahwa nilai rata-rata kemampuan berpikir kreatif siswa masih rendah yaitu 50,38 dengan skor minimal 38. dan maksimum 73 poin.

Solusi untuk mengatasi rendahnya kemampuan berpikir matematis siswa. Guru dapat menggunakan kegiatan pembelajaran untuk secara kreatif menggunakan model pembelajaran (MEA). Kegiatan ini mendukung siswa dalam melakukan kegiatan untuk mendatangkan atau memperoleh solusi atas proses berpikir siswa untuk menciptakan model matematika sebagai solusinya. Amalia et al. (2015) mengemukakan bahwa guru meyakini bahwa meskipun pembelajaran menggunakan MEA memiliki kendala dalam mengimplementasikan dan merancang MEA, namun tetap memiliki kelebihan dalam proses pemecahan masalah. Melalui pembelajaran semacam ini, siswa dapat menggunakan prosedur matematika untuk membentuk model matematika dengan kreativitas tinggi (Wessels, 2014).

Model Eliciting Activities merupakan metode pembelajaran kelompok yang digunakan untuk memahami, menjelaskan dan mengkomunikasikan konsep matematika dengan menggunakan model matematika. Dalam model eliciting activities, siswa terhubung dengan mereka dengan mengkonstruksi ide-ide matematika dalam bentuk model matematika. Model yang dikembangkan tidak harus berupa konsep baru dalam matematika, tetapi merupakan hasil pemikiran siswa sendiri dan mungkin merupakan sesuatu yang baru bagi siswa yang terkait (Rohaeti, 2018).

Chamberlin \& Moon (2005) mengemukakan bahwa model eliciting activities (MEA) dapat diterapkan dalam pembelajaran melalui langkah-langkah sebagai berikut:

1. Guru membacakan lembar permasalahan untuk mengembangkan situasi siswa.

2. Siswa menyusun pertanyaan sesuai permasalahan yang diberikan.

3. Guru dan siswa membaca soal bersama dan memastikan bahwa setiap kelompok dapat memahami pertanyaan yang akan diajukan.

4. Siswa berusaha memecahkan masalah.

5. Siswa mempersiapkan model matematisnya setelah berdiskusi dan mereview solusinya.

Selain itu, sintaks pembelajaran model MEA adalah: (1) Menggunakan metode pemecahan masalah berbasis heuristik untuk menampilkan materi, yaitu pemecahan masalah menjadi dua sub tujuan atau lebih. Heuristik, di sini tidak mengacu pada proses langkah demi langkah secara seragam atau teratur. 2) Menguraikan masalah menjadi sub-sub masalah yang lebih sederhana, mengharuskan siswa membagi masalah menjadi beberapa bagian yang masing-masing dirancang untuk memudahkan siswa dalam memecahkan masalah; 3) Menentukan masalah yang telah diuraikan menjadi beberapa bagian; 4) Menyusun sub masalah sehingga terjadi konektivitas, dan 
bertujuan untuk mengembangkan kemampuan pemecahan masalah pembelajaran matematika, 5) Memilih solusi yang tepat untuk menyelesaikan masalah (Suyatno, 2009, dalam Maryanti \& Qadriah, 2020).

Pemilihan model eliciting activities didasari oleh beberapa hasil penelitian sebelumnya. Penelitian-penelitian sebelumnya yang dirujuk berfokus pada peningkatan kemampuan berpikir kreatif melalui model eliciting activities. Beberapa hasil penelitian yang dimaksud adalah sebagai berikut:

Menurut Istianah (2013) "Peningkatan kemampuan berpikir kreatif matematik siswa yang belajar dengan model MEAs lebih baik secara signifikan daripada siswa yang belajar dengan pembelajaran biasa". Sejalan dengan itu, Budiman \& Syayyidah (2018): "peningkatan kemampuan berpikir kreatif matematis siswa yang menggunakan pendekatan Model Eliciting Activities (MEAs) lebih baik daripada siswa yang menggunakan pendekatan saintifik". Lebih lanjut, Amalia et al. (2015) mengemukankan bahwa "kemampuan berpikir kreatif matematis siswa sesudah diterapkan pembelajaran dengan MEA lebih baik bila dibandingkan dengan sebelum diterapkan pembelajaran dengan MEA". Sedangkan Zulkarnaen (2015) mengungkapkan bahwa "model eliciting activities memberikan pengaruh cukup kuat terhadap kreativitas matematis". Beberapa hasil penelitian tersebut memberikan alasan yang cukup kuat untuk memilih model eliciting activities untuk meningkatkan kemampuan berpikir kreatif siswa.

Model eliciting activities merupakan kegiatan membuat atau mengonstruksi model dan perspektif pemodelan untuk pemecahan masalah dalam pendidikan matematika (Firdausi et al., 2018). Ciri-ciri model eliciting activities (MEA) dapat membantu siswa meningkatkan kemampuan berpikir matematisnya, termasuk berpikir kreatif (Miftaqurohmah \& Hayuhantika, 2020).

Kemampuan berpikir kreatif matematis semacam ini dapat ditingkatkan dengan berbagai cara, salah satunya dengan menggunakan model pembelajaran MEAs, karena dengan menggunakan model MEAs siswa dapat dengan leluasa menyelesaikan masalah matematika dengan mengaitkan konsep-konsep yang ada. Mereka akan mendapatkan lebih banyak variasi. Hal ini menuntut siswa untuk menjadi kreatif dalam berpikir untuk menemukan solusi yang sesuai dan beragam (Susantia et al., 2019).

Pada prinsipnya penelitian ini bertujuan untuk meningkatkan kemampuan berpikir kreatif siswa kelas VIII SMP YP PGRI 4 Makassar dengan menerapkan model eliciting activities (MEA). Hasil penelitian ini diharapkan dapat memberikan manfaat sebagai berikut: (1) Penerapan model eliciting activities (MEA) akan semakin meningkatkan kemampuan berpikir kreatif siswa, sehingga mempengaruhi kinerja akademik siswa; (2) Sebagai salah satu alternatif bagi guru dalam rangka meningkatkan kemampuan berpikir kreatif siswa dalam pembelajaran matematika.

\section{B. METODE}

Jenis penelitian ini adalah penelitian tindakan kelas yang bersifat reflektif, partisipatif dan kolaboratif yang bertujuan untuk memperbaiki sistem, metode kerja, proses, isi, kemampuan atau situasi pembelajaran melalui penerapan model eliciting activities. Penelitian ini dilaksanakan dalam 2 (dua) siklus yang merupakan rangkaian kegiatan yang saling terkait, artinya pelaksanaan Siklus II merupakan kelanjutan dari Siklus I. Setiap siklus memiliki empat tahapan, yaitu: (1) mengembangkan dan merencanakan pembelajaran dan alat penelitian, (2) melakukan tindakan yaitu mengikuti model eliciting activities yang terdapat dalam RPP, mengikuti langkah-langkah model eliciting activities untuk melaksanakan proses pembelajaran, (3) Observasi meliputi observasi aktivitas siswa, observasi pelaksanaan pembelajaran dan evaluasi pemahaman konsep siswa sebagai bahan acuan dalam melakukan proses refleksi, (4) dan refleksi, yaitu pelaksanaan 
evaluasi proses dan hasil pembelajaran, berupa formulir sebagai acuan pengambilan keputusan, menghentikan tindakan atau melanjutkan ke siklus berikutnya (Arikunto, 2008, dalam Cintia et al., 2018).

Subjek penelitian ini adalah siswa kelas VIII SMP YP PGRI 4 Makassar yang berjumlah 21 siswa. Penelitian dilakukan semester ganjil tahun ajaran 2018/2019.

Instrumen yang akan digunakan dalam penelitian ini adalah: (1) Instrumen untuk menguji kemampuan berpikir kreatif yang diberikan pada setiap akhir siklus. (2) Mengisi kuesioner respon siswa untuk mengetahui respon siswa terkait penerapan model eliciting activities. Instrumen tes kemampuan berpikir kreatif disusun berdasarkan karakteristik berpikir kreatif sesuai Tabel 1:

Tabel 1. Karakteristik Berpikir Kreatif

\begin{tabular}{ccrl}
\hline No. & $\begin{array}{c}\text { Karakteristik } \\
\text { Berpikir }\end{array}$ & & \multicolumn{1}{c}{ Indikator } \\
\hline 1 & Orisinalitas & a. & $\begin{array}{l}\text { Temukan strategi lain yang tidak biasa untuk menyelesaikan } \\
\text { masalah. }\end{array}$ \\
& & b. & Berpikir berbeda dari orang lain. \\
2 & Kelancaran & c. & $\begin{array}{l}\text { Rencanakan dan terapkan berbagai strategi pemecahan masalah } \\
\text { saat dihadapkan pada masalah kompleks dan jalan buntu. }\end{array}$ \\
& & d. & Mengubah strategi pemecahan masalah bila yang terpilih \\
& & & mengalami kebuntuan dalam memecahkan masalah. \\
3 & Kelenturan & e. & Berpikir tentang berbagai cara untuk memecahkan masalah. \\
& & f. & Perkenalkan berbagai cara untuk memecahkan masalah SPLDV. \\
4 & Elaborasi & g. & Ambil langkah-langkah rinci untuk menemukan makna yang lebih \\
& & & dalam dari jawaban atau solusi masalah Anda.
\end{tabular}

Sumber: Singer (2017)

Data yang diperoleh dianalisis secara kualitatif dan kuantitatif. Data kuantitatif merupakan data yang bersumber dari data kemampuan berpikir kreatif siswa yang diujikan pada akhir siklus dan akan dikuantifikasi melalui analisis statistik deskriptif. Sedangkan data respon siswa yang diperoleh melalui kuesioner respon siswa dianalisis secara deskriptif kualitatif. Sejalan dengan tujuan penelitian ditetapkan kriteria keberhasilan penelitian ini yaitu apakah rata-rata kemampuan berpikir kreatif siswa mencapai kriteria ketuntasan minimal (KKM) $\geq 70$ sebagai syarat kreativitas minimal, dan secara klasikal minimal 85\% siswa memiliki kemampuan berpikir kreatif.

\section{HASIL DAN PEMBAHASAN}

\section{Deskripsi Hasil Penelitian}

Analisis statistik deskriptif digunakan untuk menganalisis data yang diperoleh melalui penerapan model Eliciting Activities. Hasil analisis statistik deskriptif kemampuan berpikir kreatif siswa siklus pertama dan kedua disajiikan pada Tabel 2 .

Tabel 2. Analisis Deskriptif Kemampuan Berpikir Kreatif Siswa siklus I dan II

\begin{tabular}{cccc}
\hline Statistika & Pra PTK & Siklus I & Siklus II \\
\hline Subjek & 21 & 21 & 21 \\
Mean & 50,38 & 66.86 & 81 \\
Std. deviation & 12,897 & 11.979 & 10,798 \\
Maximum & 73 & 88 & 97 \\
Minimum & 38 & 49 & 64 \\
\hline
\end{tabular}




\begin{tabular}{cccc} 
Sum & 1058 & 1383 & 1722 \\
$\begin{array}{c}\text { Persentase siswa dengan kemampuan } \\
\text { berpikir kreatif tinggi }\end{array}$ & $14,29 \%$ & $42,86 \%$ & $90,48 \%$ \\
$\begin{array}{c}\text { Persentase siswa dengan kemampuan } \\
\text { berpikir kreatif rendah }\end{array}$ & $85,71 \%$ & $61,91 \%$ & $14,29 \%$ \\
\hline
\end{tabular}

Tabel 2 menunjukkan rata-rata hasil Pra-PTK sebesar 50,38 yang diperoleh dari tes kemampuan berpikir kreatif 21 siswa pada materi SPLDV sebelum menerapkan model eliciting activities, menunjukkan bahwa tingkat kemampuan berpikir kreatif siswa berpusat pada 50,38 dengan simpangan baku 12,897 yang menunjukkan penyimpangan dari nilai rata-rata sebesar 12,897, hanya $14,29 \%$ siswa yang memiliki kemampuan berpikir kreatif tinggi. Hasil siklus pertama menunjukkan rata-rata kemampuan berpikir kreatif sebesar 66.86 yang menunjukkan bahwa kemampuan berpikir kreatif siswa berpusat pada 66.86 dengan simpangan baku 11.979 menunjukkan bahwa penyimpangan dari nilai rata-rata sebesar 11.979 , hanya $42,86 \%$ siswa yang memiliki kemampuan berpikir kreatif tinggi. Sedangkan hasil siklus kedua menunjukkan bahwa setelah menggunakan model eliciting activities rata-rata kemampuan berpikir kreatif siswa sebesar 81, hal ini menunjukkan bahwa kemampuan berpikir kreatif siswa pada materi SPLDV adalah 81 dengan simpangan baku 10,798 menunjukkan bahwa data menyimpang dari nilai ratarata sebesar 10,798, dan sebesar 90,48\% siswa yang memiliki kemampuan berpikir kreatif tinggi sehingga ketuntasan klasikal terpenuhi.

\section{Pembahasan}

Langkah-langkah dalam model eliciting activities (MEA) yang digunakan dalam pembelajaran adalah sebagai berikut: (1) Guru membacakan lembar kasus yang berisi permasalahan untuk mengembangkan situasi siswa, (2) Siswa menyusun soal sesuai dengan kasus yang diberikan, (3) Guru dan siswa membaca soal bersama dan memastikan bahwa setiap kelompok memahami soal yang diajukan, (4) Siswa berusaha menemukan solusi atas permasalahan, (5) Siswa mempersiapkan model matematika setelah berdiskusi dan mengulang solusinya.

Sebelum pelaksanaan PTK, terlebih dahulu diberikan tes untuk mengukur tingkat kemampuan berpikir kreatif siswa sebelum menerapkan model eliciting activities. Hasil yang diperoleh pada tes pra-PTK tersebut yaitu rata-rata kemampuan berpikir kreatif siswa sebesar 50,38 dengan simpangan baku sebesar 12,897. Selain itu, diperoleh informasi bahwa hanya 3 (tiga) orang adari 21 siswa yang memiliki kemampuan berpikir kreatif yang tinggi atau hanya 14,29\%. Hasil pra-PTK ini menunjukkan bahwa sebelum menerapkan model eliciting activities, kemampuan berpikir kreatif siswa masih rendah.

Selanjutnya, setelah informasi kemampuan berpikir kreatif awal siswa diketahui, pemberian tindakan siklus satu melalui model eliciting activities dilaksanakan. Setelah pelaksanaan siklus satu, siswa kembali diberikan tes untuk mengukur tingkat kemampuan berpikir kreatifnya. Hasil yang diperoleh yaitu rata-rata kemampuan berpikir kreatif siswa sebesar 66,68 dengan simpangan baku sebesar 11,979. Selain itu, telah terjadi peningkatan dari pra-PTK ke siklus satu yaitu dari 3 orang meningkat menjadi 9 orang yang memiliki tingkat kemampuan berpikir kreatif tinggi atau sebesar 42,86\%. Hasil siklus satu mulai menunjukkan perubahan berkaitan kemampuan berpikir kreatif siswa. Setelah menerapkan model eliciting activities, terjadi peningkatan walaupun belum signifikan dari Pra-PTK ke Siklus Satu.

Lebih lanjut, setelah tes siklus satu, pemberian tindakan melalui model eliciting activities dilanjutkan ke siklus dua. Hasil siklus kedua menunjukkan bahwa setelah menggunakan model eliciting activities rata-rata kemampuan berpikir kreatif siswa sebesar 81 dengan simpangan baku 10,798. Selain itu, sebesar 90,48\% siswa yang memiliki kemampuan berpikir kreatif tinggi, 
sehingga dapat dinyatakan bahwa pada siklus dua ketuntasan klasikal terpenuhi. Hasil Siklus Dua menunjukkan bahwa setelah diterapkan model eliciting activities, kemampuan berpikir kreatif siswa mengalami peningkatan dibandingkan dengan Siklus Satu. Peningkatannya cukup besar, sekitar 47,62\% (meningkat dari 42,86\% menjadi 90,48\%). Hasil yang diperoleh melalui penerapan model eliciting activities sejalan dengan beberapa hasil penelitian sebelumnya. Firdausi et al., (2018) menyatakan bahwa "Model pembelajaran MEA dapat meningkatkan kemampuan siswa pada aspek berpikir kreatif". Selanjutnya, Herawati et al. (2019) mengungkapkan bahwa "Kemampuan berpikir kreatif matematik peserta didik dengan menggunakan model elicting activities (MEAs) melampaui ketuntasan ideal/klasikal". Oleh karena itu dengan melihat hasil yang diperoleh pada Siklus II dapat dikatakan bahwa kriteria keberhasilan penelitian ini terpenuhi, yaitu rata-rata kemampuan berpikir kreatif sebesar 81 telah melampaui nilai KKM yang ditetapkan sebelumnya. Selain itu, secara klasikal setidaknya 85\% siswa memiliki kemampuan berpikir kreatif yaitu 90,48\%. Sementara itu, diketahui bahwa hasil yang diperoleh setelah langkah-langkah pembelajaran model elicting activities (MEAs) diterapkan dinyatakan memenuhi tujuan penelitian yang diharapkan yaitu meningkatkan kemampuan berpikir kreatif siswa kelas VIII SMP YP PGRI 4 Makassar. Dengan kata lain, kriteria keberhasilan penelitian ini terpenuhi.

Sebelum penelitian ini dilakukan, telah banyak penelitian terkait model elicting activities dan kemampuan berpikir kreatif, di antaranya Istianah (2013), Amalia et al. (2015), Zulkarnaen (2015), Hanifah (2015), Abdurrozak et al. (2016), Budiman \& Syayyidah (2018), dan Maryanti \& Qadriah (2020), masing-masing merupakan penelitian eksperimen. Selanjutnya, penelitian oleh (Fardah, 2012), Firdausi et al. (2018) dan Miftaqurohmah \& Hayuhantika (2020), masing-masing merupakan penelitian kualitatif. Selain itu, penelitian oleh Wessels (2014) merupakan penelitian pengembangan dan Susantia et al. (2019) merupakan penelitian studi literatur. Penelitian ini berbeda dengan penelitian sebelumnya yaitu pada metode penelitian yang digunakan. Penelitian ini merupakan penelitian tindakan kelas, berbeda dengan penelitian sebelumnya yang menggunakan metode penelitian eksperimen, kualitatif, pengembangan dan studi literatur.

\section{PENUTUP}

\section{Kesimpulan}

Berdasarkan hasil penelitian tindakan yang dilaksanakan di kelas VIII SMP YP PGRI 4 Makassar dapat disimpulkan bahwa kemampuan berpikir kreatif siswa kelas VIII SMP YP PGRI 4 Makassar dapat ditingkatkan melalui penerapan model eliciting activities. Hal ini ditunjukan dengan rata-rata nilai kemampuan berpikir kreatif siswa mengalami peningkatan yaitu dari Pra-PTK sebesar 50,38 dengan simpangan baku sebesar 12,897 meningkat menjadi 66,86 dengan simpangan baku sebesar 11,979, lalu meningkat lagi pada siklus II menjadi 81 dengan simpangan baku 10,798, yang berarti rata-rata kemampuan berpikir kreatif siswa melampaui KKM yang ditetapkan yaitu 70 . Selain itu ditinjau dari ketuntasan klasikal, terpenuhi 90,48\% dari kriteria yang telah ditentukan sebelumnya yaitu $85 \%$.

\section{Saran}

Saran bagi para praktisi pendidikan khususnya tenaga pengajar bidang matematika sebaiknya lebih kreatif dan inovatif dalam merumuskan model, metode, strategi dan metode pembelajaran yang efektif dan relevan dengan bahan ajar. Salah satu pilihannya adalah dengan model eliciting activities dalam pembelajaran matematika. 


\section{DAFTAR PUSTAKA}

Abdurrozak, R., Jayadinata, A. K., \& Isrok'atun. (2016). Pengaruh Model Problem Based Learning Terhadap Kemampuan Berpikir Kreatif Siswa. Jurnal Pena Ilmiah, 1(1), 871-880. https://doi.org/10.23819/pi.v1i1.3580

Amalia, Y., Duskri, M., \& Ahmad, A. (2015). Penerapan Model Eliciting Activities untuk Meningkatkan Kemampuan Berpikir Kreatif Matematis dan Self Confidence Siswa SMA. Jurnal Didaktik Matematika, 2(2), 38-48. https://doi.org/10.24815/jdm.v2i2.2813

Budiman, H., \& Syayyidah, K. N. (2018). Penerapan Pembelajaran Model Eliciting Activities (MEAs) Untuk Meningkatkan Kemampuan Berpikir Kreatif Matematis Siswa. Delta: Jurnal Ilmiah Pendidikan Matematika, 6(1), 11-16. https://doi.org/10.31941/delta.v6i1.540

Chamberlin, S. A., \& Moon, S. M. (2005). Scott A. Chamberlin. The Journal of Secondary Gifted Education, 17(1), 37-47.

Cintia, N. I., Kristin, F., \& Anugraheni, I. (2018). Penerapan Model Pembelajaran Discovery Learning untuk Meningkatkan Kemampuan Berpikir Kreatif dan Hasil Belajar Siswa. Jurnal Pendidikan Kimia Indonesia, 32(1), 69-77. https://doi.org/DOI: https://doi.org/10.21009/PIP.321.8

Fardah, D. K. (2012). Analisis Proses dan Kemampuan Berpikir Kreatif Siswa dalam Matematika Melalui Tugas Open-Ended. Kreano: Jurnal Matematika Kreatif-Inovatif, 3(2), 91-99. https://doi.org/10.15294/kreano.v3i2.2616

Firdausi, Y. N., Asikin, M., \& Wuryanto. (2018). Analisis Kemampuan Berpikir Kreatif Siswa Ditinjau dari Gaya Belajar pada Pembelajaran Model Eliciting Activities (MEA). PRISMA, Prosiding Seminar Nasional Matematika, 1, 239-247. https://journal.unnes.ac.id/sju/index.php/prisma/article/view/19582

Hanifah. (2015). Penerapan Pembelajaran Model Eliciting Activities (MEA) dengan Pendekatan Saintifik untuk Meningkatkan Kemampuan Representasi Matematis Siswa. Kreano, Jurnal Matematika Kreatif-Inovatif, 6(2), 191-198. https://doi.org/10.15294/kreano.v6i2.4694

Herawati, E., Somatanaya, A. A. G., \& Hermanto, R. (2019). Hubungan Self-Confindence dan Kemampuan Berpikir Kreatif Matematik Peserta Didik yang diajar Menggunakan Model Elicting Activities (MEAs). Journal of Authentic Research on Mathematics Education (JARME), 1(1), 1-9. http://jurnal.unsil.ac.id/index.php/jarme/article/view/621

Istianah, E. (2013). Meningkatkan Kemampuan Berpikir Kritis dan Kreatif Matematik Dengan Pendekatan Model Eliciting Activities (MEAs) pada Siswa SMA. Infinity Journal, 2(1), 43-54. https://doi.org/10.22460/infinity.v2i1.23

Maryanti, \& Qadriah, L. (2020). Penerapan Model Eliciting Activities untuk Meningkatkan Kemampuan Berpikir Kreatif Matematis dan Self Confidence Siswa SMA. Jurnal Ilmiah Ilmu Pendidikan, 3(3), 649-657. https://doi.org/10.24815/jdm.v2i2.2813

Miftaqurohmah, R., \& Hayuhantika, D. (2020). Profil Berpikir Kreatif dalam Penyelesaian Masalah Matematika Melalui Model Eliciting Activity Ditinjau Gaya Kognitif. JP2M (Jurnal Pendidikan Dan Pembelajaran Matematika), 6(1), 1-9. https://doi.org/10.29100/jp2m.v6i1.1738

Rohaeti, Eti, Euis, dkk. 2019. Pembelajaran Inovatif Matematika. Bandung. PT Refika Aditama.

Singer, F. M., Ellerton, N., \& Cai, J. (2013). Problem-posing research in mathematics education: New questions and directions. Educational Studies in Mathematics, 83(1), 1-7. https://doi.org/10.1007/s10649-013-9478-2

Susantia, E., Waluya, S. B., Masrukan, \& Wardono. (2019). Penggunaan MEAs untuk Meningkatkan Kemampuan Berpikir Kreatif Matematis Siswa Ditinjau dari Self- Regulation pada Pembelajaran Matematika. PRISMA, Prosiding Seminar Nasional Matematika, 2, 366-370. 
Wessels, H. (2014). Levels of Mathematical Creativity in Model-Eliciting Activities. Journal of Mathematical Modelling and Application, 1(9), 22-40. https://bu.furb.br/ojs/index.php/modelling/article/view/4048

Zulkarnaen, R. (2015). Pengaruh Model Eliciting Activities Terhadap Kreativitas Matematis Pada Siswa Kelas Viii Pada Satu Sekolah Di Kab. Karawang. Infinity Journal, 4(1), 32. https://doi.org/10.22460/infinity.v4i1.69 